Ilona Skibińska-Fabrowska'

\title{
POWRÓT DO PRZEDKRYZYSOWEJ POLITYKI PIENIĘŻNEJ A STABILNOŚĆ SYSTEMU FINANSOWEGO
}

\section{Wprowadzenie}

W trakcie kryzysu finansowego, który wybuchł w 2008 r. ${ }^{2}$, banki centralne prowadziły niezwykle aktywną politykę pieniężną. Początkowo koncentrowała się ona na utrzymaniu stabilności sektora finansowego przez dostarczanie na rynek dodatkowej płynności, z czasem coraz bardziej skupiała się na stymulowaniu gospodarek ${ }^{3}$. Władze monetarne aktywnie wykorzystywały w tym celu podstawowy instrument pozostający w ich dyspozycji - krótkoterminową stopę procentową. Szybko jednak w swojej polityce doszły do granicy zerowych stóp procentowych (w przypadku amerykańskiego Systemu Rezerwy Federalnej stało się to już pod koniec 2008 r., Europejski Bank Centralny doszedł do tego punktu nieco później, ale posunął się dalej, bowiem od połowy 2014 r. stopa depozytowa EBC jest ujemna ${ }^{4}$. Wówczas banki centralne uruchomiły niekonwencjonalne instrumenty polityki pieniężnej określane mianem quantitative easing. Polegały one, najogólniej rzecz biorąc, na dokonywaniu przez bank centralny zakupu papierów wartościowych obarczonych różnym ryzykiem, o różnych (nierzadko sięgających 30 lat) terminach zapadalności i emitowanych przez różne podmioty (publiczne, w tym rządy, i prywatne). Jednym ze skutków prowadzenia tego rodzaju polityki był (obok zwiększenia stabilności systemu finansowego

1 Dr Ilona Skibińska-Fabrowska, Instytut Ekonomii i Finansów, Wydział Ekonomiczny, Uniwersytet Marii Curie-Skłodowskiej w Lublinie.

2 Przyjmując upadek amerykańskiego banku Lehman Brothers w połowie września 2008 r. za umowną datę wybuchu kryzysu.

3 J. Janus, Niekonwencjonalna polityka pieniężna głównych banków centralnych - diagnoza korzyści i zagrożeń, http://www.pte.pl/kongres/referaty/Janus\%20Jakub/Janus\%20Jakub\%20-\%20NIEKONWENCJONALNA\%20POLITYKA\%20PIENI\%C4\%98\%C5\%BBNA\%20G\%C5\%81\%C3\%93WNYCH\%20BANK\%C3\%93W\%20CENTRALNYCH\%20\%E2\%80\%93\%20DIAGNOZA\%20KORZY\%C5\%9ACI\%20I\% 20ZAGRO\%C5\%BBE\%C5\%83.pdf [dostęp 1.10.2016].

4 www.ecb.int/stats/monetary/rates [dostęp 8.09.2016].

B. Coere, The ECB's Operational Framework in Post-Crisi Times, https://www.ecb.europa.eu/press/ $\mathrm{key} / \mathrm{date} / 2016 / \mathrm{html} / \mathrm{sp} 160827 . \mathrm{en} . \mathrm{html}$ [dostęp 12.08.2016]. 
i wspierania gospodarki) wzrost sum bilansowych banków centralnych, stąd określanie tego rodzaju działań mianem polityki bilansowej. W przypadku Systemu Rezerwy Federalnej był on blisko pięciokrotny ${ }^{6}$, a w przypadku Europejskiego Banku Centralnego (który rozpoczął realizację programu luzowania ilościowego w 2014 r.) blisko dwukrotny. Poprawa sytuacji gospodarczej i stopniowe wychodzenie z kryzysu nie tylko sfery finansowej, ale i realnej rodzi dylematy związane z powrotem do prowadzenia przez banki centralne konwencjonalnej (przedkryzysowej) polityki pieniężnej. Wśród wielu wątków dyskusji na ten temat stale powraca kwestia wpływu całej operacji na stabilność systemu finansowego. Celem artykułu jest weryfikacja hipotezy o dużym zagrożeniu dla stabilności systemu finansowego, jakie może rodzić powrót do tradycyjnej polityki pieniężnej.

Artykuł składa się z trzech części. W pierwszej części zostaną wskazane skutki polityki bilansowej prowadzonej w ostatnich latach przez banki centralne, przy czym punktem odniesienia będą przede wszystkim doświadczenia Systemu Rezerwy Federalnej ${ }^{7}$. W drugiej części na podstawie przeglądu literatury zostaną wskazane możliwe scenariusze powrotu do konwencjonalnej polityki pieniężnej i ich potencjalne skutki dla stabilności systemu finansowego. W podsumowaniu zostaną zawarte wnioski dotyczące przygotowania strategii powrotu do konwencjonalnej polityki monetarnej, która zminimalizuje zagrożenia dla stabilności systemu.

\section{Polityka bilansowa w warunkach kryzysu}

Pierwsze symptomy zaburzeń na rynkach finansowych pojawiły się już w 2007 r. Ich nasilenie, $\mathrm{z}$ kulminacją $\mathrm{w}$ postaci upadłości banku Lehman Brothers nastąpiło na jesieni 2008 r. W reakcji na wydarzenia na rynkach finansowych banki centralne rozpoczęły łagodzenie polityki pieniężnej, począwszy od obniżania krótkoterminowych stóp procentowych oraz modyfikowania procedur przeprowadzania zarówno operacji otwartego rynku, jak i transakcji depozytowo-kredytowych. Z czasem wobec osiągnięcia granicy zerowych stóp procentowych sięgnęly po niestandardowe,

6 L.J. Mester, Recent Developments in U.S. Monetary Policy: From Extraordinary Back to Ordinary, file://C:/Users/U132622/Downloads/sp\%2020150323\%20recent\%20developments\%20in\%20the\%20us\% 20monetary\%20policy\%20pdf\%20(1).pdf [dostęp 10.08.2016].

7 Jest to bank centralny, który jest obecnie najbliższy zakończeniu prowadzenia niekonwencjonalnej polityki pieniężnej w odróżnieniu od Europejskiego Banku Centralnego, który cały czas realizuje programy skupu aktywów. 
niestosowane dotychczas powszechnie instrumenty polityki monetarnej ${ }^{8}$. Polegały one przede wszystkim na prowadzeniu skupu aktywów finansowych o różnej strukturze zapadalności emitowanych przez różne podmioty. Programy te określane są ogólną nazwą quantitative easing lub z uwagi na wpływ, jaki mają na wielkość i strukturę bilansu realizującego je banku centralnego, polityką bilansową.

Bankiem centralnym, który pierwszy rozpoczął prowadzenie polityki bilansowej ${ }^{10}$, był Bank Japonii. Jednak ze względu na globalne znaczenie gospodarki i systemu finansowego to System Rezerwy Federalnej (SRF) jest najczęstszym przedmiotem analiz. Funkcjonuje on na rynku finansowym, na którym dominującą rolę odgrywa sektor kapitałowy. Stąd wsparcie udzielane przez SRF w warunkach kryzysu kierowane było głównie do tego segmentu. Obejmowało ono programy skupu aktywów, przeprowadzane w trzech rundach luzowania ilościowego, które trwały łącznie od grudnia 2008 r. do października 2014 r. Towarzyszyła im przeprowadzona w połowie 2011 r. operacja Twist, polegająca na równoczesnej sprzedaży przez bank centralny krótkoterminowych papierów dłużnych (o terminie zapadalności do 3 lat) i zakupie papierów o dłuższym terminie zapadalności (od 6 do 30 lat). W wyniku tych operacji suma bilansowa SRF wzrosła z 900 mld USD (w lipcu 2007 r.) do około 4,5 bln USD (w 2015 r.) ${ }^{11}$. Zmianie uległa równocześnie struktura bilansu banku centralnego - po stronie aktywów pojawiły się w nim skarbowe i komercyjne papiery dłużne obarczone ryzykiem (często wysokim). Po stronie pasywów obok gotówki w postaci banknotów (1,36 bln USD) występują bardzo wysokie płynne rezerwy instytucji depozytowych (2,57 bln USD) ${ }^{12}$. Celem, jaki przyświecał SRF (i innym bankom centralnym) przy prowadzeniu polityki bilansowej, było ${ }^{13}$ :

- zwiększenie płynności systemu finansowego (dostarczenie dodatkowej płynności do systemu finansowego),

- usprawnienie transmisji impulsów monetarnych do sfery realnej,

- prowadzenie akomodacyjnej polityki pieniężnej w warunkach zerowych stóp procentowych,

8 B. Bernanke, V. Reinhard, B. Sack, Monetary Policy Alternatives at the Zero Bound: An Empirical Assessment, http://muse.jhu.edu/journals/eca/summary/v2004/2004.2bernanke.html [dostęp 1.10.2016]; L.B. Smaghi, Conventional and Unconventional Monetary Policy, ICMB, Geneva 2009, s. 5-11.

9 Z. Polański, Przemiany funkcji pożyczkodawcy ostatniej instancji w czasie kryzysu, w: Współczesna bankowość centralna, red. W.L. Jaworski, A. Szelągowska, CeDeWu, Warszawa 2014, s. 95-98.

10 Określenie to w dalszej części artykułu będzie używane zamiennie z luzowaniem ilościowym i quantitative easing.

11 L.J. Mester, op.cit.

12 R. Greenwood, S.G. Hanson, J.C. Stein, The Federal Reserve's Balance Sheet as a Financial-Stability Tool, http://www.people.hbs.edu/shanson/Jackson_Hole_final_GHS.pdf [dostęp 15.09.2016].

13 The Role of Central Bank Balance Sheet in Monetary Policy, „ECB Economic Bulletin” 2015, No. 4, https://www.ecb.europa.eu/pub/pdf/other/art01_eb201504.en.pdf [dostęp 10.09.2016], s. 3-4. 
- kształtowanie warunków ekonomicznych w kierunku obniżenia długoterminowej stopy procentowej.

Wszystkie wymienione cele były podporządkowane realizacji podstawowego zadania banku centralnego - utrzymania stabilnego poziomu cen (w przypadku banków realizujących strategię celu inflacyjnego) oraz pełnego zatrudnienia (w przypadku SRF) ${ }^{14}$.

Podobne programy quantitative easing uruchomił Europejski Bank Centralny. Ich skala i zasięg są różne od działań SRF, co w dużej mierze wynika ze specyfiki funkcjonowania Unii Gospodarczej i Walutowej, a w jej ramach strefy euro, w której jednolitej polityce pieniężnej nie towarzyszy wspólna polityka fiskalna. W związku z powyższym EBC jest ostrożniejszy w dokonywaniu skupu aktywów, m.in. z powodu ciągle obecnych głosów krytycznych dotyczących ewentualnego przekroczenia mandatu udzielonego bankowi centralnemu przez kraje członkowskie. Należy jednak podkreślić, że zmiany struktury i wielkości dotyczą także bilansu Europejskiego Banku Centralnego, chociaż ich skala jak na razie jest niższa ze względu na to, że luzowanie ilościowe w Europie ciągle jest prowadzone i nie jest to zakończony proces.

$\mathrm{Z}$ punktu widzenia rynku finansowego i jego funkcjonowania najistotniejsze konsekwencje luzowania ilościowego ma skuteczne obniżenie długoterminowych rynkowych stóp procentowych. Jako przykład można podać szacunki przeprowadzone dla gospodarki amerykańskiej wskazujące na obniżenie oprocentowania 10-letnich papierów skarbowych o 91 pkt. baz., a papierów komercyjnych zabezpieczonych na nieruchomościach (MBS) o 113-156 pkt. baz. ${ }^{15}$ Kilkuletni okres poluzowania polityki pieniężnej, owocujący tanim pieniądzem wpłynął na przyzwyczajenie się inwestorów do tej sytuacji i wręcz, jak stwierdzają niektórzy analitycy, na uzależnienie się od niej, co może rodzić w przyszłości negatywne skutki ${ }^{16}$. Pozytywny bez wątpienia wpływ wywarła natomiast polityka bilansowa na stabilizowanie długoterminowych oczekiwań inflacyjnych, co stało się jednym z czynników chroniących gospodarki przed niestabilnością cen w czasie kryzysu. Jednak ekonomiści wskazują, że prowadzenie polityki bilansowej wygenerowało dodatkowe koszty ${ }^{17}$. W aktywach banków centralnych pojawiły się komercyjne papiery dłużne obarczone wysokim ryzykiem wynikającym ze zmienności ich ceny. Zakup przez bank centralny papierów powiązanych z rynkiem hipotecznym (MBS) sprawił, że w powszechnym odczuciu to SRF

14 The Role of Central Bank Balance Sheet in Monetary Policy, „ECB Economic Bulletin” 2015, No. 4, https://www.ecb.europa.eu/pub/pdf/other/art01_eb201504.en.pdf [dostęp 10.09.2016], s. 15.

15 A. Blinder, T.J. Jordan, D. Kohn, F.S. Mishkin, Exit Strategy, International Center for Monetary and Banking Studies, Geneva 2013, s. 20.

16 Długofalowe skutki polityki niskich stóp i poluzowania polityki pieniężnej, red. E. Balcerowicz, „Zeszyty BRE Bank - CASE" 2013, nr 129, s. 17.

17 A. Blinder, T.J. Jordan, D. Kohn, F.S. Mishkin, op.cit., s. 20-21. 
stał się odpowiedzialny za sytuację na rynku mieszkaniowym. Tym samym niezależność władz monetarnych została naruszona. Podobne konsekwencje dla reputacji banku ma zakup rządowych papierów dłużnych sugerujący zaangażowanie banku centralnego w monetyzację długu publicznego.

\section{Powrót do konwencjonalnej polityki pieniężnej}

Dyskusja na temat możliwych scenariuszy powrotu do konwencjonalnej polityki pieniężnej rozpoczęła się na długo przedtem, nim zakończyły się programy luzowania ilościowego. Najwcześniej (w październiku 2014 r.) skup aktywów został zakończony w Stanach Zjednoczonych i siłą rzeczy proponowane rozwiązania odnoszą się do sytuacji SRF. Najczęściej przedmiotem dyskusji jest propozycja powrotu do prowadzenia przedkryzysowej polityki monetarnej (zarówno jeżeli chodzi o jej cel, jak i wykorzystywane narzędzia) w trzech etapach ${ }^{18}$. Przy czym sposób ponownego wprowadzenia konwencjonalnej polityki pieniężnej powinien zostać uzależniony, po pierwsze, od kondycji gospodarki, po drugie zaś od reakcji rynków finansowych na wdrażane rozwiązania ${ }^{19}$. W początkowym okresie wychodzenia z niekonwencjonalnej polityki pieniężnej powinno zostać zatrzymane luzowanie ilościowe. Następnie powinno rozpocząć się podnoszenie krótkoterminowych stóp procentowych banku centralnego do poziomu wynikającego z równania Taylora (przy założeniu, że nadal dominująca $\mathrm{w}$ polityce banków centralnych pozostanie strategia bezpośredniego celu inflacyjnego). I wreszcie powinna zostać przeprowadzona operacja „zmniejszania” bilansów banków centralnych, być może nie do poziomu przedkryzysowego, ale z pewnością dużo niższego niż obecny. Ten klasyczny scenariusz rodzi bardzo wiele zagrożeń dla stabilności systemu finansowego. Po pierwsze, skuteczność banku centralnego zależy w dużej mierze od przewidywalności decyzji władz monetarnych. W związku z osłabieniem reputacji banków centralnych (zwłaszcza w przypadku obwinianego o co najmniej przyczynienie się do wybuchu kryzysu SRF problem ten jest widoczny) wydaje się, że prawdopodobieństwo „niedopasowania się" decyzji o podwyżce stóp do oczekiwań rynku jest wysokie. Rozminięcie się decyzji banku z oczekiwaniami rynków może grozić zaburzeniami na rynkach finansowych i koniecznością ich stabilizowania. Podwyżka stóp procentowych w tak

18 Długofalowe skutki..., op.cit., s. 19.

19 A. Nocoń, Monetary Policy of the Federal Reserve System from the Perspective of Exit Strategies, „Journal of Economics and Management University of Economics in Katowice” 2015, Vol. 21(3), s. 167. 
istotnej dla globalnego rynku finansowego gospodarce jak gospodarka amerykańska wywołuje daleko idące skutki w skali międzynarodowej, szczególnie w krajach rozwijających się. Ilustracją tego problemu jest destabilizujący wpływ podwyżek stóp procentowych w Stanach Zjednoczonych na waluty krajów Azji Wschodniej opisany przez Ogawę i Wanga ${ }^{20}$.

Stopniowe zmniejszanie portfela aktywów przez banki centralne może być przeprowadzone na drodze sprzedaży lub wygasania zobowiązań wraz z upływem terminów ich zapadalności. Trudna do przewidzenia pozostaje reakcja rynków finansowych na taką operację. Prawdopodobne wydaje się wystąpienie zjawisk odwrotnych do wywołanych luzowaniem ilościowym, wzrost długoterminowej stopy procentowej, ograniczenie płynności w poszczególnych segmentach rynku finansowego i w konsekwencji destabilizacja rynków finansowych. W tym kontekście ciekawy jest problem charakteru podejmowanych decyzji, czy powinny one być dyskrecjonalne, czy oparte na regułach. Proponowane są różne podejścia ${ }^{21}$ :

- ilościowe, oparte na wolumenach dokonywanych transakcji, np. z uwzględnieniem stałego harmonogramu sprzedaży,

- oparte na cenach aktywów, bank dokonywałby sprzedaży tylko w warunkach gwałtownej zmienności rynku.

Również scenariusz polegający na utrzymywaniu nabytych w ramach luzowania ilościowego papierów dłużnych aż do terminów ich zapadalności rodzi ryzyko destabilizacji. Głównie dlatego, że zacieśnianie polityki pieniężnej poprzez redukowanie portfeli aktywów przez banki centralne nie byłoby uzależnione od sytuacji w gospodarce. Wyłączny wpływ na nie miałyby historyczne decyzje dotyczące struktury i terminów zapadalności kupowanych w trakcie kryzysu aktywów ${ }^{22}$.

Kolejnym zagrożeniem dla stabilności systemu finansowego jest możliwość zmaterializowania się ryzyka finansowego, po stronie banków centralnych związanego z upadłością emitentów papierów dłużnych. Oczywiście straty w bankach centralnych nie miałyby bezpośredniego wpływu na ich funkcjonowanie, ale znalazłyby odbicie w sferze fiskalnej gospodarek. Bez wątpienia bowiem kolejnym istotnym aspektem konstruowania strategii wyjścia $\mathrm{z}$ niekonwencjonalnej polityki pieniężnej rodzącym ryzyko dla stabilności finansowej jest konieczność ścisłego powiązania polityki fiskalnej i monetarnej23. Destabilizacja finansów publicznych w wyniku

20 E. Ogawa, Z. Wang, Efects of Quantitative Easing Monetary Policy Exit Strategy on East Asian Currencies, „The Developing Economies” March 2016, Vol. 54, No. 1, s. 109-117.

21 A. Blinder, T.J. Jordan, D. Kohn, F.S. Mishkin, op.cit., s. 57-58.

22 P. Turner, op.cit., s. 14

23 A. Belke, Global Liquidity and Strategies of Exit From Unconventional Monetary Policies, „Economic Research - Ekonomska Istraživanja" 2016, Vol. 29, s. 286-287. 
kryzysu, szczególnie widoczna w krajach Unii Gospodarczej i Walutowej, również wymaga strategii powrotu do stanu przedkryzysowego. Luźna polityka pieniężna prowadzona w warunkach niskich stóp procentowych sprawiła, że koszty obsługi zadłużenia publicznego były bardzo niskie. Podniesienie stóp procentowych i wstrzymanie przez banki centralne skupu rządowych papierów dłużnych niekorzystnie odbije się na finansach publicznych ${ }^{24}$. Może to mieć negatywny wpływ na stabilność systemu finansowego. Jest to kolejny argument za koniecznością koordynacji polityki fiskalnej i monetarnej w procesie powrotu do strategii przedkryzysowych. Przy czym należy zauważyć, że część autorów jest zdania, że najpierw należy wyjść z niekonwencjonalnej polityki fiskalnej, a dopiero w drugiej kolejności z monetarnej ${ }^{25}$.

Ważnym wątkiem dyskusji na temat strategii wyjścia z niekonwencjonalnej polityki pieniężnej jest problem inflacji. Jej pojawienie się byłoby w oczywisty sposób destabilizujące dla rynków finansowych. W literaturze przytaczane są argumenty wskazujące na to, że zbyt długo prowadzona luźna polityka monetarna jest potencjalnie „inflacjogenna”26. Za bardzo stymuluje ona gospodarkę, nadmiernie zwiększa płynność systemu bankowego i zmienia poziom oczekiwań inflacyjnych. Zatem najlepszym sposobem przeciwdziałania wybuchowi inflacji jest odejście od niekonwencjonalnej polityki pieniężnej.

Na tle dyskusji na temat strategii wyjścia z niekonwencjonalnej polityki pieniężnej interesująco brzmią głosy zalecające pozostawienie bilansów banków centralnych na niezmienionym poziomie i dalsze prowadzenie programu skupu aktywów ${ }^{27}$. Przytaczana argumentacja wskazuje na możliwy pozytywny wpływ tego rodzaju polityki na stabilność finansową ${ }^{28}$. To spostrzeżenie opiera się na stwierdzeniu istnienia na rynkach finansowych wysokiego popytu ze strony inwestorów na krótkoterminowe papiery dłużne. Sytuacja ta przypomina tę sprzed wybuchu kryzysu finansowego, kiedy to powszechne było finansowanie długoterminowych aktywów krótkoterminowymi pasywami. Stało się to jedną z głównych przyczyn destabilizacji systemu finansowego. Chcąc uniknąć podobnych problemów w przyszłości, bank centralny

24 Nie wydaje się jednak akceptowalna sytuacja, w której to bank centralny, oddziałując na długoterminową stopę procentową, będzie decydował o strategii zarządzania długiem publicznym.

25 A. Blinder, T.J. Jordan, D. Kohn, F.S. Mishkin, op.cit., s. 61.

26 A. Belke, op.cit., s. 288-289.

27 B. Bernanke, Should the FED Keep Its Balance Sheet Large?, https://www.brookings.edu/blog/benbernanke/2016/09/02/should-the-fed-keep-its-balance-sheet-large/ [dostęp10.09.2016]; R. Greenwood, S.G. Hanson, J.C. Stein, The Federal Reserve's Balance Sheet as a Financial-Stability Tool, http://www.people. hbs.edu/shanson/Jackson_Hole_final_GHS.pdf [dostęp 15.09.2016].

28 Odwołuje się ona do sytuacji Systemu Rezerwy Federalnej, który po zakończeniu w październiku 2014 r. programu skupu aktywów używa dwóch quasi-instrumentów polityki pieniężnej: oprocentowania nadwyżkowych płynnych rezerw instytucji depozytowych i transakcji repo na termin overnight przeprowadzanych z podmiotami rynku finansowego. 
mógłby emitować krótkoterminowe papiery, finansując w ten sposób zakup rządowych papierów dłużnych o dłuższych terminach zapadalności. Takie rozwiązanie przyniosłoby dwojakiego rodzaju skutki. Po pierwsze, zostałyby ograniczone prywatne emisje papierów o podobnym charakterze, $\mathrm{z}$ natury rzeczy obarczone wyższym ryzykiem. Po drugie zaś zostałby zapewniony zbyt dla papierów rządowych, dla których emisje prywatne stanowią konkurencję. Ponadto podkreślane jest pozytywne oddziaływanie transakcji przeprowadzanych przez bank centralny na szybkość i czytelność transmisji impulsów pieniężnych do gospodarki realnej. I wreszcie możliwość dokonywania transakcji zakupu papierów dłużnych przez bank centralny i utrzymywanie w ślad za tym wysokich stanów płynnych rezerw poprawia efektywność ewentualnego wykonywania przez bank centralny funkcji pożyczkodawcy ostatniej instancji. Wdrożenie takiego rozwiązania miałoby kilka skutków dla banku centralnego. Po pierwsze, do instrumentarium polityki monetarnej na trwałe weszłyby narzędzia polityki bilansowej, stając się narzędziami konwencjonalnymi (wykorzystywanymi w codziennej praktyce $)^{29}$. Po drugie, suma bilansowa banku centralnego pozostałaby trwale wysoka, ale jej struktura po stronie aktywów w stosunku do sytuacji obecnej uległaby zmianie. Powinien bowiem nastąpić spadek udziału komercyjnych papierów dłużnych na rzecz papierów rządowych.

\section{Podsumowanie}

Mimo że perspektywa powrotu do konwencjonalnej polityki pieniężnej przez banki centralne wydaje się jeszcze odległa (zwłaszcza w przypadku Europejskiego Banku Centralnego, który nadal prowadzi aktywną politykę bilansową), to nie jest zbyt wcześnie na dyskusję o tym, jak proces ten powinien przebiegać. Jest to niezwykle istotne zwłaszcza ze względu na zagrożenia dla stabilności systemu finansowego, jakie może on generować. W mojej opinii najistotniejsze $\mathrm{z}$ nich wynikają z możliwego wzrostu długoterminowych stóp procentowych, czyli z możliwego powtórzenia się scenariusza z początku kryzysu finansowego, ze wszystkimi tego konsekwencjami dla rynków finansowych (straty po stronie inwestorów, zamieranie obrotów w różnych segmentach rynków, utrudniony dostęp do źródeł finansowania, zahamowanie inwestycji itp.). Spowoduje to konieczność powrotu banków centralnych do prowadzenia niekonwencjonalnej polityki pieniężnej w celu zapobieżenia

29 W tym miejscu nasuwa się pytanie, jakie instrumenty zostałyby uruchomione przez bank centralny w przypadku wybuchu kolejnego kryzysu. Pozostaje ono na razie bez odpowiedzi. 
narastaniu niestabilności w systemie finansowym. Taki scenariusz znacząco obniży wiarygodność władz monetarnych, która przy realizacji strategii celu inflacyjnego jest niezbędna. Moim zdaniem oprócz ryzyk wymienionych w artykule prawdopodobnie istnieją jeszcze ryzyka nierozpoznane, które mogą ujawnić się dopiero z czasem. Dodatkową komplikacją jest z pewnością fakt, że skutki wyjścia z niestandardowej polityki pieniężnej przez jeden bank centralny będą odczuwane w skali globalnej. Wydaje się, że w obliczu tak wielu niewiadomych i tak licznych zagrożeń nie da się całkowicie bezpiecznie (z punktu widzenia stabilności systemu finansowego) wdrożyć strategii powrotu do konwencjonalnej polityki pieniężnej. Czynnikiem, który może przyczynić się do ograniczenia ryzyka dla stabilności finansowej, jest odpowiednia polityka informacyjna. Komunikowanie uczestnikom rynku założeń dotyczących strategii wyjścia z niestandardowej polityki monetarnej i wyjaśnianie motywów podejmowania kolejnych decyzji musi się stać integralną częścią samej strategii. Drugim elementem niezwykle istotnym dla płynnego powrotu do przedkryzysowej polityki monetarnej jest wdrożenie polityki makroostrożnościowej, która przygotuje i do pewnego stopnia uodporni system finansowy na mogące pojawić się turbulencje. Oznacza to, że polityka pieniężna wymaga daleko idącej koordynacji nie tylko z polityką fiskalną, ale także z polityką makroostrożnościową. I tylko daleko idąca współpraca w zakresie przygotowania strategii powrotu do przedkryzysowej polityki monetarnej może zminimalizować negatywne skutki, jakie potencjalnie rodzi ona dla stabilności systemu finansowego.

\section{Bibliografia}

Aizenman J., Binici M., Hutchison M.M., The Transmission of Federal Reserve Tapering News to Emerging Financial Markets, „NBER Working Paper Series” 2014, No. 19980.

Belke A., Global Liquidity and Strategies of Exit From Unconventional Monetary Policies, „Economic Research - Ekonomska Istraživanja” 2016, Vol. 29.

Bernanke B., Should the FED Keep Its Balance Sheet Large?, https://www.brookings. edu/blog/ben-bernanke/2016/09/02/should-the-fed-keep-its-balance-sheet-large/

Bernanke B., Reinhard V., Sack B., Monetary Policy Alternatives at the Zero Bound: An Empirical Assessment, http://muse.jhu.edu/journals/eca/summary/v2004/2004.2bernanke.html

Blinder A., Jordan T.J., Kohn D., Mishkin F.S., Exit Strategy, International Center for Monetary and Banking Studies, Geneva 2013. 
Coere B., The ECB's Operational Framework in Post-Crisi Times, https://www.ecb.europa. $\mathrm{eu} / \mathrm{press} / \mathrm{key} /$ date $/ 2016 / \mathrm{html} / \mathrm{sp} 160827$.en.html

Długofalowe skutki polityki niskich stóp i poluzowania polityki pieniężnej, red. E. Balcerowicz, „Zeszyty BRE Bank-CASE” 2013, nr 129.

Greenwood R., Hanson S.G., Stein J.C., The Federal Reserve's Balance Sheet as a Financial-Stability Tool, http://www.people.hbs.edu/shanson/Jackson_Hole_final_GHS.pdf

Janus J., Niekonwencjonalna polityka pieniężna głównych banków centralnych - diagnoza korzyści i zagrożeń, http://www.pte.pl/kongres/referaty/Janus\%20Jakub/Janus\%20Jakub\% 20-\%20NIEKONWENCJONALNA\%20POLITYKA\%20PIENI\%C4\%98\%C5\%BBNA\% 20G\%C5\%81\%C3\%93WNYCH\%20BANK\%C3\%93W\%20CENTRALNYCH\%20\% E2\%80\%93\%20DIAGNOZA\%20KORZY\%C5\%9ACI\%20I\%20ZAGRO\%C5\%BBE $\%$ C5\%83.pdf

Mester L.J., Recent Developments in U.S. Monetary Policy: From Extraordinary Back to Ordinary, file://C:/Users/U132622/Downloads/sp\%2020150323\%20recent\%20developments\%20in\%20the\%20us\%20monetary\%20policy\%20pdf\%20(1).pdf

Nocon A., Monetary Policy of the Federal Reserve System from the Perspective of Exit Strategies, "Journal of Economics and Management University of Economics in Katowice” 2015, Vol. 21(3).

Ogawa E., Wang Z., Efects of Quantitative Easing Monetary Policy Exit Strategy on East Asian Currencies, „The Developing Economies” March 2016, Vol. 54, No. 1.

The Role of Central Bank Balance Sheet in Monetary Policy, „ECB Economic Bulletin” 2015, No. 4, https://www.ecb.europa.eu/pub/pdf/other/art01_eb201504.en.pdf

Smaghi L.B., Conventional and Unconventional Monetary Policy, ICMB, Geneva 2009.

Turner P., TheExit from Non-Conventional Monetary Policy: What Challenges?, „BIS Working Papers" 2014, No. 448.

Wspótczesna bankowość centralna, red. W.L. Jaworski, A. Szelągowska, CeDeWu, Warszawa 2014.

\section{The return to the pre-crisis monetary policy versus stability of financial system}

Faced with the financial crisis in 2008, the central banks used conventional monetary policy instruments. However, the problem of zero lower bond forced them to use unconventional monetary policy instruments - quantitative easing carried out as part of the so-called central bank balance sheet politics and relying on the buying by the central bank of different kinds of financial assets - resulting in stabilization of the situation on financial markets in conditions of low 
long-term interest rates. Balance sheet totals of the central banks rose repeatedly. Their structure also changed. At present possible effects for the stability of the financial system of the return to the pre-crisis monetary policy are the topic of debate. The exit strategy is giving rise to a significant risks and the coordination of economic policy and the transparency of action taken by monetary authorities can only minimize possible negative effects

Keywords: exit strategy, unconventional monetary policy, financial stability

\section{Le retour à la politique monétaire d'avant la crise et la stabilité du système financier}

Après l'éclatement de la crise financière du 2008, les banques ont appliqué des instruments traditionnels de la politique monétaire. Cependant, après avoir atteint le taux d'intérêt proche du zéro, elles ont dû utiliser des instruments nonconventionnels, notamment des quantitiative easing, réalisés dans le cadre de la - soi-disant - politique du bilan de la banque centrale qui consiste à l'achat par la banque centrale des actifs financiers différents. Par conséquent, la situation sur les marchés financiers a été stabilisée dans les conditions des taux d'intérêt à long terme faibles. Les totaux du bilan des banques centrales ont augmenté à plusieurs reprises. Leur structure a également changé. Actuellement, une discussion est menée au sujet d'une probable influence du retour à la politique monétaire d'avant la crise sur la stabilité du système financier. Puisque la stratégie de sortie provoque une série de risques, c'est uniquement la coordination de la politique économique et la transparence des démarches entreprises par les autorités monétaires qui peut minimiser d'éventuels effets négatifs.

Mots-clés: stratégie de sortie, oilitique monétaire non-conventionnelle, stabilité du système financier

\section{Возврат к докризисной денежно-кредитной политике и финансовая стабильность}

После начала финансового кризиса в 2008 году центральные банки использовали традиционные инструменты денежно-кредитной политики. Тем не менее, после достижения нулевой процентной ставки они прибегли 
к нетрадиционным инструментам денежной политики - количественному смягчению, которое осуществляется в рамках политики по балансу центрального банка, опираясь на покупке центральным банком различных видов финансовых активов. В результате их использования ситуация на финансовых рынках стабилизировалась в условиях низких долгосрочных процентных ставок. Суммы балансов центральных банков увеличились в несколько раз и изменилась их структура. В настоящее время рассматриваются возможные последствия для стабильности финансовой системы возврата к докризисной денежно-кредитной политике. Стратегия выхода порождает много рисков и только координация экономической политики и прозрачность действий, предпринимаемых монетарными властями, могут свести к минимуму возможные негативные последствия.

Ключевые слова: стратегия выхода, нетрадиционная денежно-кредитная политика, стабильность финансовой системы 